\section{マウスを用いたシスチンの経口投与が個体の免 疫系に与える影響}

○田中 賢治、柴草哲朗、栗原 重一

味の素株式会社イノベーション研究所

【背景と目的】これまでに我々は、マウスへのシス チン経口投与が LPS 刺激後の生存率を有意に改善 すること、またこの作用機序の一部としてシスチン 輸送体である $\mathrm{xCT}$ を発現する単球系細胞における シスチンからシステインへの代謝が、シスチン経口 投与後の効果を発現する上で重要である可能性を示 してきた。一方、 $\mathrm{xCT}$ は細胞性/液性免疫を司る リンパ球には発現しないとされている。そこで今回、 シスチン経口投与が免疫系細胞に与える影響を明ら かにすることを目的にシスチンが細胞性 / 液性免疫 系へ与える影響について解析を実施した。

【方法】 12 週齢雌性 BALB/c マウスにシスチン（200 $\mathrm{mg} / \mathrm{kg}$ ) あるいは溶媒を経口投与し、経時的に血液、 脾藏、腸管およびパイエル板を採取した。各臓器に おけるシスチンおよびシステイン量は高感度 HPLC を用いて解析した。また同様のマウスから脾細胞を 単離し、0.2〜0.8mM のシスチンもしくはシステイ ンを添加し、Concanavalin A (ConA) およびLPS を用いた in vitroリンパ球幼若化試験を実施した。

【結果】シスチン $200 \mathrm{mg} / \mathrm{kg}$ 経口投与 0.5 時間後、 血漿、脾臓、腸管、パイエル板においてシスチン濃 度の上昇が確認され、投与 4 時間後に投与前のレベ ルに戻ることが分かった。またシステイン濃度は、 シスチン経口投与 0.5 時間後に血漿、腸管、パイエ ル板にて上昇が確認され、脾臓では投与 0.5 から 2 時間後に上昇することが明らかとなった。一方、マ ウス脾細胞を用いて in vitro リンパ球幼若化試験を 実施したところ、ConA および LPS 刺激後、シス チン添加では影響が観察されなかったのに対して、

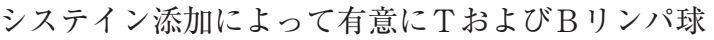
の増殖が増強した。

【考察と結論】以上のマウスを用いた研究により、 腸管および脾臓やパイエル板などのリンパ器官にお いて、シスチンは経口投与後速やかにシステインへ 代謝されることが明らかとなった。またin vitroリ ンパ球幼若化試験の結果から、シスチンではなくシ ステインによって細胞性 / 液性免疫共に誘導される 可能性が示された。これまでの結果と既報の知見を 併せると、シスチン経口投与後、腸管やリンパ器官 中の $\mathrm{xCT}$ を発現する単球等の細胞においてシスチ ンからシステインの代謝が誘導され、そのシステイ ンによってリンパ球の活性が増強される可能性が考 えられた。
アミノ酸による生体反応改善の試み：マウス腸 管虚血再灌流モデルにおけるシスチン・テアニ の効果

○宮国 泰已 ${ }^{1), 2}$ 、深柄 和彦 ${ }^{1)}$ 、李 基成 ${ }^{3)}$ 、柳川 将志 ${ }^{4)}$ 、 村越 智 ${ }^{1)}$ 、栗原 重 $^{5 \text { ) 、井上 佳子 }}{ }^{5)}$ 、高山忠利 ${ }^{2)}$ 、 安原 洋 ${ }^{1)}$

1) 東京大学医学部附属病院手術部

2) 日本大学医学部消化器外科

3）東京大学医学部附属病院胃食道外科

4) 東京大学農学部獣医外科

5）味の素イノベーション研究所

【背景】シスチンおよびテアニン（以下、CT）は、 共に抗酸化物質であるグルタチオン (GSH) の合成 を上昇させ、侵襲時の生体反応を改善すると期待さ れているアミノ酸である。実際、CTの経口摂取が 侵襲時の炎症反応を抑制し免疫能低下を防ぐ効果が 報告されている。今回、大手術や shockの際に生 じる臓器障害の重要な機序の一つと考えられている 腸管虚血再灌流で、CT の前投与が 1) 生存を改善 するか、2) GSH とそれに関連するアミノ酸值に影 響を及ぼすか、マウスモデルで検討した。

【方法】：実験 1.ICR マウス $(\mathrm{n}=17)$ を 2 群（CT70： $\mathrm{n}=7$ 、Vehicle : n=10) に分けた。CT70 群は、CT $70 \mathrm{mg} / \mathrm{kg} / \mathrm{day}$ を経口的に 1 日 1 回 5 日間投与。 Vehicle 群にはその溶媒のみ投与。最終投与 2 時間 後に上腸間膜動脈 (SMA) 75 分間 clamp 施行。再 灌流後の生存を $48 \mathrm{~h}$ 観察。実験 2 . マウス $(n=35)$ を 3 群（Vehicle : n=11、CT140 : n=14、CT280： $\mathrm{n}=10 ）$ に分け、実験 1 と同様に 5 日間投与（CT 0、 140、280 mg/kg/day） L、SMA75 分間 clamp 施行。 解除後の生存を観察。実験 3. マウス $(n=67)$ を 3 群 (Vehicle : n=24、CT280: n=20、vehicle/sham : n=23）に分けた。 5 日間、前投与し、CT280、 Vehicle 群には、SMA60 分間 clamp 施行。clamp 前 (pre)、再灌流 3、6、9h 後に犠死せしめ、小腸 組織（口側と肛側に分割）、肝臓、肺を採取。各臓 器をホモジネイト、遠心分離後、上清の GSH、 GSSG（酸化型 GSH）、シスチン、システイン值を 高速液体クロマトグラフィーで、グルタミン・グル タミン酸值をアミノ酸分析機で測定した。

【結果】実験 1 . 生存時間に群間の差なし。実験 2 . 生 存時間は CT280 群がVehicle 群に比べ有意に改善 ( $\mathrm{p}=0.03) 、 C T 140$ 群も改善傾向を示した。実験 3.CT 投与の有無で、各臓器 pre の GSH、GSSG、各アミ ノ酸值に有意な変化は認めなかった。また、再灌流 後の何れの時間も、CT280群とVehicle 群の間で、 各臓器の GSH值に有意な差を認めなかった。しかし、 回腸の GSSG 值 (平均值 \pm 標準誤差、 $\mu \mathrm{mol} / \mathrm{mg}$ tissue) は、vehicle/sham、CT280、Vehicle の 順 に pre $(0.1 \pm 0.1 、 0.0 \pm 0.0 、 0.1 \pm 0.1) 、 3 \mathrm{hr}(0.2$ $\left.\pm 0.0 、 0.5 \pm 0.1^{*} 、 0.4 \pm 0.1\right) 、 6 \mathrm{hr}(0.2 \pm 0.0 、 0.3$ $\pm 0.0 、 0.3 \pm 0.1) 、 9 \mathrm{hr}(0.1 \pm 0.0 、 0.2 \pm 0.0 、 0.1$ 土0.0) であった（ ${ }^{*} \mathrm{p}<0.05$ vs.vehicle/sham、pre、 ANOVA)。空腸・回腸共にGSSG、システイン、 グルタミン酸の值は、CT280 群で、再灌流後に有 意な上昇を示した。

【結語】CT の前投与は、腸管虚血再灌流後の生存を 用量依存性に改善した。その機序として、GSH 反 応系の修飾が示唆された 
ロイシン投与による筋線維型変換の可能性

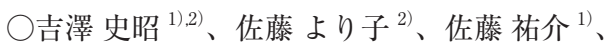
菅原邦生 ${ }^{1), 2}$

1) 宇都宮大学農学部生物資源科学科

2) 東京農工大学大学院連合農学研究科

【目的】ロイシンは、mTOR シグナル伝達経路を介 してタンパク質合成や遺伝子発現を刺激する作用を もつ。また、その長期摂取は、寿命の遅延や骨格筋 のミトコンドリア生合成を促進する。一方、mTOR や Raptor を骨格筋特異的に欠損させたマウスでは、 筋線維の遅筋的特性、特に酸化的代謝能が減弱する ことが明らかになっている。演者らは、ラットにロ イシンを単回投与すると腓腹筋において一部の遅筋 遺伝子の発現が増加することをマイクロアレイ解析 から見出した。これらのことから、ロイシンを投与 して筋細胞の mTOR を活性化させれば、筋線維の 遅筋的特性、ミトコンドリアの酸化的代謝能が強化 されるとの仮説のもとに研究を進めている。

【方法】《in vivo》絶食させた 5 週齢の Wistar 系雄 ラットに、ロイシンを胃内投与 $(135 \mathrm{mg} / 100 \mathrm{~g}$ 体重) した。投与 $1 、 3$ 時間後にヒラメ筋（遅筋）拈よび 長趾伸筋（速筋）を摘出し、ロイシン投与による mTOR 経路の活性化を確認するため、mTOR、

S6K1、4E-BP1 のリン酸化状態を解析した。また、 2 種類の筋肉における遅筋の特性に関連する遺伝子、 解糖系遺伝子等の発現を、それぞれの mRNAを qRT-PCR で測定することで評価した。《in vitro》 筋管を形成させたマウス筋芽細胞株 $\mathrm{C} 2 \mathrm{C} 12$ を用い て、ロイシンによる遺伝子発現制御における mTOR 経路の関与を調べた。HBSS 培地で 3 時間 培養した後にロイシン $(10 \mathrm{mM})$ を添加し、10 分 後に mTOR 経路の活性を、1 時間後に遺伝子発現 を調べた。

【結果および考察】《in vivo》ロイシン投与 3 時間 後のヒラメ筋では、遅筋の特性に関連する遺伝子 (Myl3、Myh7、Tnnil、Tfam、Atp5o、Cycs) の 発現量が増加した。一方、長趾伸筋では（Myl3、 Myh7）の発現量のみが増加した。また、速筋の構 造タンパク質を制御する転写因子 Myod は長肢伸 筋で減少し、解糖系遺伝子 (Hk2、Eno3) は何れ の筋肉でも変化しなかった。これらのことから、ロ イシンは遅筋の特性に関連する遺伝子の発現を選択 的に増加させることが示唆された。また、mTOR 経路は、長趾伸筋よりもヒラメ筋においてロイシン によって強く刺激されることが示唆された。《in vitro》ロイシンを添加した $\mathrm{C} 2 \mathrm{C} 12$ 筋管では、遅筋の 特性に関連する遺伝子（Myl3、Myh7、Tnnt1、

Tnnil、Tnnc1、Tfam）の発現量が増加した。この 作用はラパマイシンのロイシンとの同時添加により 抑制されたことから、ロイシンによる遺伝子発現制 御は mTOR シグナル伝達経路を介することが示唆 された。
HepG2 細胞においてロイシン欠乏時にATF4 経路を介して応答する microRNA の発見とその 機能解析

○山村 淳貴、加藤 久典

東京大学総括プロジェクト機構総括寄附講座 食と生命

【背景と目的】microRNAs（miRNAs）は小分子 non-coding RNA の 1 種であり、標的遺伝子の mRNA に作用することでその分解や翻訳の抑制を 誘導する因子であるが、生体内の栄養状態の変化に 対して応答を示すかは不明であった。そこで本研究 ではまずヒト肝臓ガン由来細胞 HepG2 において、 必須アミノ酸の 1 種であるロイシンを欠乏した際に 発現変化する miRNAsを探索した。また同じく HepG2 細胞内でアミノ酸欠乏時に活性化する転写 因子であるATF4 の過剩発現を施し、miRNA 発現 プロファイルを調べることで、応答機序解析も試み た。

【材料と方法】<実験 $1>$ HepG2 細胞を MEM 培地 もしくはロイシンを含まない MEM 培地で 12 時間 培養した後に total RNA を回収し、miRNA 3.0 Array（Affymetrix）を利用して miRNA 発現プロファ イルを取得した。く実験 $2>\mathrm{HepG} 2$ 細胞に対し ATF4の過剩発現ベクターのトランスフェクショ ンを 24 時間施した後に total RNA を回収し、く実 験 $1>$ と同様の方法で miRNA 発現プロファイルを 取得した。<実験 3>HepG2 細胞に対しATF4を 標的とする siRNA のトランスフェクションを 6 時 間施した後に、培地を MEM もしくはロイシンを 含まない MEM 培地に交換し、16 時間培養を続け た後に total RNA を回収し、定量 PCRによって miR-663a の発現量を測定した。

【結果と考察】マイクロアレイを利用した網羅的解 析によって、ロイシン欠乏時に発現上昇する 12 個 の miRNAs が見出された。また ATF4 の過剩発現 により、203 個の miRNAs が発現上昇することが 明らかになった。両実験結果を比較したところ、 miR-663a が共通して発現上昇していた。さらに siRNA によってATF4をノックダウンすると、ロ イシン久乏を施した際の miR-663a の発現上昇が大 きく抑制されたことから、この応答機序には ATF4 が関与していることが分かった。 miR-663a は TGF $\beta 1$ を標的とする事が報告されている。TGF $\beta 1$ は 細胞増殖の抑制因子として広く知られており、本研 究によってアミノ酸栄養欠乏時に細胞増殖活性が促 進される新しい機構を提示することが出来た。 


\section{分岐鎖アミノ酸代謝と代謝性疾患}

○北浦 靖之

名古屋大学大学院生命農学研究科

必須アミノ酸であるロイシン、イソロイシン、バ リンは分岐鎖アミノ酸 (Branched-Chain Amino Acids：BCAA）と総称され、分解系の第 1 、第 2 ステップは共通の酵素により代謝される。特に第 2 ステップに存在する分岐鎖 $\alpha$-ケト酸脱水素酵素 (branched-chain $a$-keto acid dehydrogenase : $\mathrm{BCKDH}$ ) 複合体による脱炭酸反応は、その分解の 律速段階と考えられ、この BCKDH 複合体は特異 的キナーゼ（BCKDH kinase：BDK）によるリン酸 化によって不活性化される。BCAA 代謝は様々な 疾病で変動することが知られており、肝硬変では BDK 活性の低下に伴う BCKDH 複合体活性の上昇 により血中 BCAA 濃度が低下し、肝臓でのアルブ ミン合成が抑制されると考えられている。そのため、 BCAA は肝硬変患者の低アルブミン血症の改善薬 として使用されている。近年、遺伝性の神経疾患患 者において BDK 遺伝子の変異が発見され、血中 BCAA 濃度が低下しており、BCAA 投与による改 善が動物モデルを用いた実験において確認されてい る。一方、インスリン抵抗性を伴う肥満・2 型糖尿 病では、高インスリン血症により全身での BDK 活 性が上昇し BCKDH 複合体活性が低下するため、 血中 BCAA 濃度の上昇がみられ、BCAA が 2 型糖 尿病のマーカーとして有用であると考えられている。 これら BCAA 代謝の変動が疾病の原因もしくは結 果であるか不明であるため、本研究室では遺伝子改 変技術により BCAA 分解を立進させたマウスを作 製し、代謝性疾患の発症について解析を行っており、 本研究で得られた新たな知見を紹介する。 